\title{
Study of Relationship between Affective Variables and Academic Achievement among Adolescents
}

\author{
Dr. Md. Mahmood Alam ${ }^{1} *$
}

\section{ABSTRACT}

This study examined the affective variables, namely study habits and academic self concept to determine if they are correlated and have an impact on adolescents' academic achievement. Subjects comprised 480 randomly selected students of class XII ${ }^{\text {th }}$ of the $10+2$ schools in Darbhanga town (Bihar). They were asked to complete Study Habit Inventory by Dr. M. Mukhopadhyay \& Dr. D. N. Sansanwal (2002) and Academic Self Concept Scale (ASCS) by Reynolds et al. (1980) in normal classroom situation. Statistical analyses were performed to ascertain the relationship between affective variables \& academic achievement and their effects on academic achievement of adolescents (both rural and Urban). Findings of the study revealed that (1) there is a significant positive correlation between study habits, academic self concept and academic achievement and (2) there is a significant difference between boys and girls( both rural and urban) on the variables, study habits, academic self concept and academic achievement. It was recommended that similar research with appropriate methodology and design may be used to ascertain the degree of conformity which this research has on the above said variables.

Keywords: Affective variables, Study habits, Academic self concept, Academic Achievement.

Adolescence is a transitional period during which a child is becoming, but is not yet, an adult. During this period, the adolescent establish their emotional and psychological independence and try to achieve personal identity. It is a time when many physical, psychological and behavioural transformations happen and when adolescents develop a lot of the habits, behavioural patterns and relationships they will take into their adulthood (Committee on Adolescent Health Care Services and Models of Care for Treatment 2008). Adolescents with poor habits and skills are known to develop high risk behaviours which lead to long lasting social and academic consequences.

\footnotetext{
${ }^{1}$ Assistant Professor, MANUU College of Teacher Education-Sambhal, U.P., A Constituent College of Maulana Azad National Urdu University, Hyderabad, India

*Responding Author

(c) 2016 I M Alam; licensee IJIP. This is an Open Access Research distributed under the terms of the Creative Commons Attribution License (http://creativecommons.org/licenses/by/2.0), which permits unrestricted use, distribution, and reproduction in any Medium, provided the original work is properly cited.
} 
Many students fail not because they lack ability, but because they do not have adequate study skills (Menzel, 1982). Good students are not born but are made by constant and deliberate practice of good study habits, for which there is no substitute (Ames \& Archer, 1988). Thus, in order to improve academic performance of students, it seems essential to improve their study habits without which desired outcomes cannot be achieved. Robinson (2000) found that certain bad study habits result in poor academic performance whereas certain good study habits result in high academic performance. Creemers and Reynold (2000), on the basis of data of National Assessment of Educational Progress, demonstrated a positive relationship between good study habits and academic performance of 8th and 9th Grade students. Similarly, Gilbert and Rollick (1996) suggested good study habits to significantly enhance academic performance of the pupils. Most research that has been done on factors that influence academic achievement concentrate more on the cognitive factors, while the affective factors are ignored (Sikhwari 2004). The affective aspect of the students should receive as much attention as the cognitive aspect in academic investigation and endeavours (Sikhwari 2004). Variance in academic achievement can be related to affective variables, of which self-concept and motivation are the most important (Van der Lith, J. M. 1991). Areepattamannil and Freeman (2008) concur with Van der Lith, J. M. (1991) when they state that academic self-concept have the most potential of being directly influenced and should therefore be of primary concern.

Thus study habits and academic self-concept have been selected by the researcher to be the two affective variables that this study will focus on. As Gilman, Huebner, and Furlong (2009) remark: If the ultimate goal of schools is to educate young people to become responsible and critically thinking citizens who can succeed in life, understanding factors that stimulate them to become active agents in their own learning is critical. Because of this reason, it is crucial to know and to understand which factors are responsible for determining, predicting or for causing variance in academic achievement.

\section{CONCEPTUAL FRAMEWORK}

\section{Study Habits: Concept and Definition}

The term study habit means various methods and practices adopted by the students to learn in a systematic and efficient way, when opportunity is given. It calls for knowing where and how to obtain facts, be able to organize, classify and arrange facts and make intelligent use of time. Study habit is auto nominally, learned behavior pattern that enable the student to acquire how to study. A good study habit has actually developed a behavior pattern which enables him to sit down and began working on his assignment with a minimum fuss and maximum concentration. According to dictionary of education (2007), "study habit indicate settled tendency of practice and thought to acquire knowledge and information from the book." Study habit is also defined as the devotion of time and attention to acquire information or knowledge especially from books or in other words it's the pursuit of academic knowledge by a detailed investigation of a subject or situation (Oxford Dictionary \& Thesaurus of English Language, 2003). 
Good (1973) define the term study habits as: "The student's way of study whether systematic, efficient or inefficient etc." Study habits, in this study, have been considered to be sum total of scores obtained on the nine different kinds of study behaviors viz., comprehension, concentration, task orientation, study sets, interaction, drilling, supports, recording and language depicted by Study Habit Inventory by Dr. M. Mukhopadhyay and Dr. D. N. Sansanwal (2002).

\section{Academic Self-Concept: Concept and Definition}

An academic self-concept is the overall self-perception and thinking of the individual regarding academic ability. It is comprised of a set of attitudes, beliefs and perceptions held by the students about their academic skills and performance (Lent, Brown \& Gore 1997). Academic self-concept is referred to as a person's self-evaluation regarding specific academic domains or abilities (Trautwein, et al. 2006). In other words, academic self-concept is how students do school work or feel about themselves as learners (Guay, et al. 2003; Harter, 1998).

Academic self-concept is one sub facet of the general self-concept that has been linked to academic achievement. A higher academic self-concept has been associated with better academic achievement (Marsh 1990). Academic self concept in this study have been considered to be the sum of scores obtained on the seven constructs of academic self-concept Scale (ASCS) by Reynolds et al.(1980) viz., grade and effort dimension, study habits/organization selfperceptions, peer evaluation of academic ability, self-confidence in academics, satisfaction with school, self-doubt about ability, and self-evaluation with external standards.

\section{Academic Achievement: Concept and Definition}

Academic achievement has always been considered as a key criterion to judge one's total potentialities and capacities. Academic achievement of an individual is influenced partly by his ability to adjust to his environment, partly by his special abilities, intelligence and aptitude which are an integral part of his personality and partly by the intensity of drives and motives which serve as the impelling force for his activities. Hence academic achievement occupies a very important place in education as well as in the learning process. Academic achievement, according to Crow and Crow (1969), is defined as the extent to which a learner is profiting from instruction in a given area of learning i.e. achievement is reflected by the extent to which skill and knowledge has been imparted to him. In view of other authors such as Goods (1958), Biswas and Aggarwal (1971) there seems to be considerable similarities in as much as all of them place emphasis on knowledge attained or skill developed in academic subjects and usually designated by test scores. It is exposition of his/her present level of performance.

Thus, academic achievement refers to the degree of level of success and that of proficiency attained in some specific area concerning scholastic and academic work. Academic achievement in this study has been considered to be total marks obtained by student in 11th class examination. 


\section{OBJECTIVES}

1. To study the relationship between affective variables, namely study habits, academic selfconcept and academic achievement of students.

2. To compare boys and girls (both rural and urban) on the measure of affective variables, namely study habits, academic self-concept and academic achievement.

\section{Hypotheses}

Based on the review of literature, the following hypotheses were formulated:

H1: There will be significant positive relationship between study habits and academic achievement of students.

H2: There will be significant positive relationship between academic self-concept and Academic achievement of students.

H3: There will be significant positive relationship between study habits and academic Selfconcept of students.

H4: There will be significant difference between boys and girls in respect of their study habits.

H5: There will be significant difference between boys and girls in respect of their academic self- concept.

H6: There will be significant difference between boys and girls in respect of their academic achievement.

H7: There will be significant difference between rural and urban students in respect of their study habits.

H8: There will be significant difference between rural and urban students in respect of their academic self-concept.

H9: There will be significant difference between rural and urban students in respect of their academic achievement.

\section{METHODOLOGY}

This study utilized survey techniques due to its descriptive nature. This section is comprised of sample, research tools and procedure of the data collection.

\section{Sample}

A random sample of 480 XII ${ }^{\text {th }}$ class students of the 10+2 schools (two hundreds forty boys: 120 rural \& 120 urban; two hundreds forty girls: 120 rural \& 120 urban) participated in the study. The government high schools named below also run 10+2 Classes. The ages of the students ranged between 16 and 19 years with an average age of 17.5 years. 


\begin{tabular}{|c|c|c|c|c|}
\hline \multicolumn{2}{|c|}{ Respondents } & \multirow{2}{*}{ 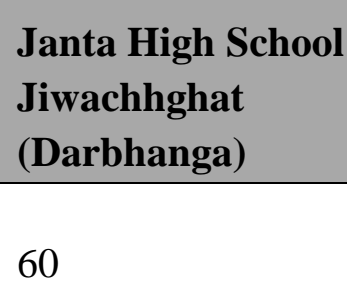 } & \multirow{2}{*}{$\begin{array}{l}\text { Zila High School } \\
\text { (Darbhanga) }\end{array}$} & \multirow{2}{*}{$\begin{array}{l}\text { Total } \\
120\end{array}$} \\
\hline \multirow{2}{*}{ Boys } & Rural & & & \\
\hline & Urban & 60 & 60 & 120 \\
\hline \multirow{2}{*}{ Girls } & Rural & 60 & 60 & 120 \\
\hline & Urban & 60 & 60 & 120 \\
\hline \multicolumn{2}{|c|}{ G. Total } & 240 & 240 & 480 \\
\hline
\end{tabular}

\section{Tools Used}

The following instruments were used for collecting the data to measure the variables of the study.

\section{Study Habit Inventory by Dr. M. Mukhopadhyay and Dr. D. N. Sansanwal (2002)}

Study Habit Inventory comprises 52 items pertaining to nine sub-components namely Comprehension, Concentration, Task Orientation, Study Size, Interaction, Drilling, Supports, Recording and Language. The instrument uses a Likert-type scale ranging from always, frequently, sometimes, rarely and never. The reliability coefficient of the whole inventory was worked out using split-half method and is found to be 0.91 which is fairly high.

\section{Academic Self Concept Scale (ASCS) by Reynolds et al. (1980)}

The Academic Self Concept Scale is a 40-items Likert- type scale that measures the academic aspect of the general self-concept among college students. Test-retest reliability for the ASCS is reported to be .88 with an internal consistency of 0.91 . The reliability coefficients for the subscales range from 0.59 to 0.92 (Reynolds, 1988).The validity of the scale as established using the administration of the instrument to undergraduate college students was reported to be 0.44 .

\section{Academic Achievement}

Aggregate marks secured by students in the annual examination of class $\mathrm{XI}^{\text {th }}$ conducted by the Bihar Board of Intermediate Examination (2013) were taken as the academic achievement of the students. These marks were collected from the office records of the concerned institutions and used in the analyses of the data.

\section{Statistical Analyses}

The researcher used the following statistical techniques for analyses of the data.

I. Descriptive Statistics: Mean and SD

II. Correlational Statistics: Coefficient of Correlation ' $r$ '

III. Inferential Statistics’'- test 


\section{Procedure}

The administration of the tools viz., Study Habit Inventory by Dr. M. Mukhopadhyay and Dr. D. N. Sansanwal (2002) and Academic Self Concept Scale (ASCS) by Reynolds et al. (1980) were completed following the instructions given by the respective authors.

\section{Analyses of the Data}

Keeping in view the objectives as well as design of the study, coefficient of correlation and ' $t$ ' test were used for the analysis of the data. Pearson's Coefficient of Correlation was computed to analyze the relationships. Mean, Standard Deviation and ' $\mathrm{t}$ ' test were used to find the significance of difference between the means.

\section{RESULTS AND DISCUSSION}

1. Correlation of affective variables, namely study habits, academic self concept and academic achievement

The study was conducted to ascertain the extent of relationship between independent variables (Academic Self Concept and Study Habits) and dependent variable (Academic Achievement) using Pearsons' Product Moment Coefficient of correlation. Results of the correlation are presented in Table No.1

Table No.1, Correlation Matrix of Affective Variables, namely Study Habits, Academic Self Concept and Academic Achievement

\begin{tabular}{|c|c|c|c|}
\hline Variables & Study Habits & $\begin{array}{l}\text { Academic } \quad \text { Self } \\
\text { Concept }\end{array}$ & $\begin{array}{l}\text { Academic } \\
\text { Achievement }\end{array}$ \\
\hline Study Habits & 1 & & \\
\hline Academic Self Concept & $\begin{array}{l}0.102 \\
(.05)\end{array}$ & 1 & \\
\hline Academic Achievement & $\begin{array}{l}0.165 \\
(.01)\end{array}$ & $\begin{array}{l}0.125 \\
(.01)\end{array}$ & 1 \\
\hline
\end{tabular}

Perusal of table- 1 establishes that there is a significant positive correlation between study habits and academic achievement. It implies that good study habits results into better academic achievement and vice-versa. The reason for the good study habits leading to better academic achievement may be the better and effective time management, along with systematic, efficient and effective strategies of acquiring and using knowledge results into good study habits. Such results are also reported by Creemers and Reynold (2000) and Onwuegbuzie et al. (2001). Thus the hypothesis $\mathrm{H} 1$ is accepted. In case of correlation between academic self concept and academic achievement, the significant positive correlation indicates that academic self concept is directly proportional to academic performance meaning thereby better academic self concept 
results into proportional academic achievement and vice-versa. The possible reason for this result may be that academic self-concept has a direct positive effect on academic achievement as academic self-concept improves self-perceptions by eliminating self-defeating thoughts and other negative behaviours. This perception may positively affect the confidence and motivate individuals in the learning process. This result is in accordance with the researches of Marsh \& Scalas, (2011). Thus the hypothesis H2 is accepted. Concerning the relationship between study habits and academic self concept, the significant positive correlation between them points that self concept in general and academic self concept in particular enables the individuals to hold a realistic view of themselves and their academic abilities. They might perceive and relate their intellectual and academic competence with cognitive interests intelligently which is beneficial for the students in positive academic behaviors and attitudes and ultimately better study habits. Thus the hypothesis H3 is accepted.

\section{Comparison between gender (boys and girls) on the selected variables.}

The comparison between the samples on the selected variables was done by testing the significance of difference between their means by using t-tests. The results are presented in the following tables.

Table No.2, Comparison of Gender on the Selected Variables

\begin{tabular}{|c|c|c|c|c|c|}
\hline \multirow{3}{*}{ Variables } & \multicolumn{4}{|l|}{ Gender } & \multirow{3}{*}{ t-value } \\
\hline & \multicolumn{2}{|l|}{\begin{tabular}{|l|} 
Boys \\
$(240)$
\end{tabular}} & \multicolumn{2}{|l|}{$\begin{array}{l}\text { Girls } \\
(240) \\
\end{array}$} & \\
\hline & $\mathbf{M}_{1}$ & $\sigma_{1}$ & $\mathbf{M}_{2}$ & $\sigma_{2}$ & \\
\hline Study Habits & 131.16 & 23.15 & 139.62 & 21.87 & $\begin{array}{l}4.16 \\
(0.01) \\
\end{array}$ \\
\hline $\begin{array}{l}\text { Academic } \\
\text { Self Concept }\end{array}$ & 109.71 & 18.65 & 98.15 & 17.66 & $\begin{array}{l}6.97 \\
(0.01)\end{array}$ \\
\hline $\begin{array}{l}\text { Academic } \\
\text { Achievement }\end{array}$ & 350.21 & 61.22 & 365.17 & 62.93 & $\begin{array}{l}3.22 \\
(0.01)\end{array}$ \\
\hline
\end{tabular}

Perusal of table-2 reveals significant difference between boys and girls favoring girls on the variable, study habits. Thus it may be concluded that girls manage their time effectively and engages themselves in regular and sustained concentration with the effective habits of study (plan/place, a definite time table and taking brief of well organized notes) in an environment that is conducive to studying. They are amenable to the use of cognitive restructuring in improving their study behaviors in order to achieve excellent academic performance. On the other hands, disruptive and inattentive behaviors in boys may results into their lower levels of academic 
success. This finding is in line with the finding of Ukwueze (2009). Thus the hypothesis H4 is substantiated. On the other hands, this table depicts that boys have higher mean scores on academic self concept in comparison to their female counterparts. This significant result favouring boys might be due to their maximum emphasis on positive aspects of self and higher preparation to accept their positive evaluation enabling them to increase their activities in desirable direction for facing difficulties with confidence and doing tasks that must be done. This result is in consonance with the research of Kling, et al. (1999). Thus the hypothesis H5 is substantiated. Significant result favoring girls on the measure of academic achievement might be due to the changing cultural taboo and providing better attention by the government and the society in order to develop their untapped and hidden potential, to improve on their academic achievement and erase the old stereotype that places boy above girls on academic issues. This result is in line with the studies of Cokley and Moore (2007) and Chavous, T. M. et al. 2008). Thus the hypothesis H6 is substantiated.

\section{Comparison between rural and urban on the selected variables.}

The comparison between the samples on the selected variables was done by testing the significance of difference between their means by using t-tests. The results are presented in the following tables.

Table No.3, Comparison of Locale on the Selected Variables

\begin{tabular}{|c|c|c|c|c|c|}
\hline \multirow{3}{*}{ Variables } & \multicolumn{4}{|l|}{ Locale } & \multirow{3}{*}{ t-value } \\
\hline & \multicolumn{2}{|l|}{$\begin{array}{l}\text { Rural } \\
(240)\end{array}$} & \multicolumn{2}{|l|}{$\begin{array}{l}\text { Urban } \\
\text { (240) }\end{array}$} & \\
\hline & $\mathbf{M}_{1}$ & $\sigma_{1}$ & $\mathbf{M}_{2}$ & $\sigma_{2}$ & \\
\hline Study Habits & 115.23 & 19.58 & 125.11 & 22.01 & $\begin{array}{l}2.71 \\
(0.01)\end{array}$ \\
\hline $\begin{array}{l}\text { Academic } \\
\text { Self Concept }\end{array}$ & 96.68 & 16.68 & 101.36 & 19.25 & $\begin{array}{l}1.83 \\
\text { (N.S.) }\end{array}$ \\
\hline $\begin{array}{l}\text { Academic } \\
\text { Achievement }\end{array}$ & 372.12 & 61.05 & 383.75 & 64.82 & $\begin{array}{l}2.02 \\
(0.05)\end{array}$ \\
\hline
\end{tabular}

Table-3 revealed that there is a significant difference between rural and urban students favouring the latter with respect to study habits. This significant difference at 0.01 levels suggests that urban students may have higher educational aspiration \& motivation level and place more value 
on academic activity. This approach may lead them to structure the work environment accordingly, cope with distractions if any and concentrate more on various aspects and strategies of academic endeavour which helps in formation of appropriate academic habits. This finding is consistent with the investigation made by Sarwar; et al. (2009). Thus the hypothesis H7 is accepted. Non-significant result between rural and urban students on the measure of academic self concept might be due to the fact that rural students are equally receptive to and benefit from family help to keep them aspired and motivated and utilize their talents by visualizing distal goals. This perception might affect the confidence level in the learning process which, in turn, helps them equally in academic self concept formation. In a study by Devi \& Prasanthi ((2004), no significant difference between rural and urban on the measure of academic self concept is reported. Thus the hypothesis H8 is rejected. The significant difference at 5\% level favouring urban students on the measure of academic achievement might be due to the greater access to many resources \& opportunities and above all the location of school which provides great opportunities to students' success and extend into students' aspiration for the future. Thus the hypothesis H9 is accepted.

\section{CONCLUSION}

The findings suggest that there is variety of factors, both cognitive and affective, that may affect adolescents' achievement and consequently develop an academic self-concept accordingly. The literature has indicated that study habits and academic self-concept are important affective variables that could contribute towards the variance in the academic achievement of adolescents. This is a reminder to the professionals in the field that skills of study habits might be 'taught' just as subject matter. This may be quite useful in fostering students' academic self concept. Based on the findings of the present study, it is worth mentioning to pay more attention to affective factors such as study habits and academic self concept that affect academic achievement. As Gilman, Huebner, and Furlong (2009) remark: If the ultimate goal of schools is to educate young people to become responsible and critically thinking citizens who can succeed in life, understanding factors that stimulate them to become active agents in their own learning is critical.

\section{REFERENCES}

Ames, R. and Archer, J. (1988), “Achievement goals in the classroom: Students learning strategies and motivation process”, Journal of Psychology, 8, 260-267.

Areepattamannil, S. and Freeman, J.G. (2008), “Academic achievement, academic self-concept, and academic motivation of immigrant adolescents in the Greater Toronto Area Secondary Schools”, Journal of Advanced Academics, 19(4), 700-743.

Biswas, A. and Aggarwal, J.C. (1971), "Encyclopaedia Dictionary and Directory of Education”, 1, Academic Publishers, Delhi-5.

Berg, A.S. (1990), “The relationship between self concept and, family factors and academic achievement”, M.Ed. Dissertation, University of the Witwatersrand, Johannesburg. 
Chavous, T.M., Smalls, C., Rivas-Drake, D., Griffin, T. and Cogburn, C. (2008), "Gender matters too: The influences of school racial discrimination and racial identity on academic engagement outcomes among African American adolescents”, Developmental Psychology, 44, 637-654

Cokley, K. and Moore, P. (2007), "Moderating and mediating effects of gender and psychological disengagements on the academic achievement of African American College students”, Journal of Black Psychology, 33, 169-187.

Committee on Adolescent Health Care Services and Models of Care for Treatment, Prevention, and Healthy Development, National Research Council (2008), “Adolescent Health Services: Missing Opportunities”, National Academies Press, Washington, DC.

Creemers, B. and Reynold, D. (2000), "School effectiveness and school improvement", International Journal of Research, Policy and Practice, 22, 4-11.

Crow, L. D. and Crow, A. (1969), “Adolescent Adjustment and Development”, Mc Graw-Hill Company, United States.

Devi, T.K. and Prasanti, S. (2004), "Self concept of adolescents in urban and rural areas", Indian Psychol Rev., 62, 202-206.

Gilbert, J. N. and Rollick, T. (1996), "Evaluation of a life skill program with children”, Journal of Elementary School Guidance and Counselling, 31, 139-152.

Gilman, R., Huebner, E. S. and Furlong, M. J. (2009), "Handbook of positive psychology in schools," Routledge, New York.

Good, C.V. (1973), “Dictionary of Education (3rd Ed.)”, McGraw Hill Book Company, New York.

Guay, F., Marsh, H. W. and Boivin, M. (2003), “Academic self-concept and academic achievement: Developmental perspectives on their causal ordering”, Journal of Educational Psychology, 95, 124-136.

Harter, S. (1998), “The development of self-representations”, In Damon, W. and Eisenberg, N. (Ed), Handbook of child psychology, John Wiley and Sons, New York, 3(5), 553-617.

Kizlik, R. D. (2001), “ABC of academic success”, Harper \& Co, London.

Kling, K. C., Hyde, J. S., Showers, C. J. and Buswell, B. N. (1999), “Gender differences in selfesteem: A meta-analysis”, Psychological Bulletin, Vol. 125, pp. 470-500.

Lent, R.W., Brown, S. D., and Gore, P. A. Jr. (1997), "Discriminant and predictive validity of academic self-concept, academic self-efficacy, and mathematics-specific self-efficacy", Journal of Counselling Psychology, 44(3), 307-315.

Marsh, H. W. (1990), “A multidimensional, hierarchical self-concept: Theoretical and empirical justification”, Educational Psychology Review, 2, 77-172.

Marsh, H. W. and Scalas, L. F. (2011), "Self-concept in learning: Reciprocal effects model between academic self-concept and academic achievement”, In S. Järvelä (Ed.), Social and emotional aspects of learning, Oxford Academic Press, England, 191-198.

Menzel, W. E. (1982), "How to study effectively”, Oxford University Press, London. 
Muhammad Sarwar, Muhammad Bashir, Muhammad Naemullah Khan and Muhammad Saeed Khan (2009), "Study-orientation of high and low academic achievers at secondary level in Pakistan”, Educational Research and Review, 4(4), 204-207.

Mukhopadhyaya, M. and Sansanwal, D.N. (2002), "Study Habit Inventory (SHI)”, National Psychological Corporation, Agra, 3-11.

Onwuegbuzie, A. J., Slate, J.R. and Schwartz, R.A. (2001), "Role of Study Skills in Graduate Level Educational Research Courses”, The Journal of Educational Research, 94 (4), No. 238-246.

Oxford Dictionary \& Thesaurus of English Language (2003), “Oxford University Press”, Oxford.

Reynolds, W. M., Ramirez, M. P., Magrina, A. and Allen, J. E. (1980), “Initial development and validation of the academic self-concept scale”, Educational and Psychological Measurement, 40, 1013-1016.

Robinson, H. H. (2000), “Effective study”, Harper and Brothers, New York.

Sikhwari, T.D. (2004), "The relationship between affective factors and the academic achievement of students at the University of Venda”, Unpublished M.Ed. Dissertation, Pretoria: Unisa, 22-30.

Trautwein, U., Lüdtke, O., Marsh, H. W., Köller, O. \& Baumert, J. (2006), “. Tracking, grading, and student motivation: Using group composition and status to predict self-concept and interest in ninth-grade mathematics”, Journal of Educational Psychology, 98(4), 788-806.

Ukwueze, A.C. (2009), "The effect of Cognitive Restructuring on Study Habits among Secondary School Students”, Journal of Education and Applied Psychology, 2 (1), No. 183-189.

UNICEF (2002), “. Putting a face and a memory to each student’s name: An interview with Mrs. Erlinda J. Valdez”, Principal Francisco Benitez Elementary School.

Van der Lith, J.M. (1991), "Die invloed van kognitiewe en affektiewe toetredingseienskappe van leerlinge op hulle prestasies in die skool milieu”, Education Bulletin, 35, 74-81. 